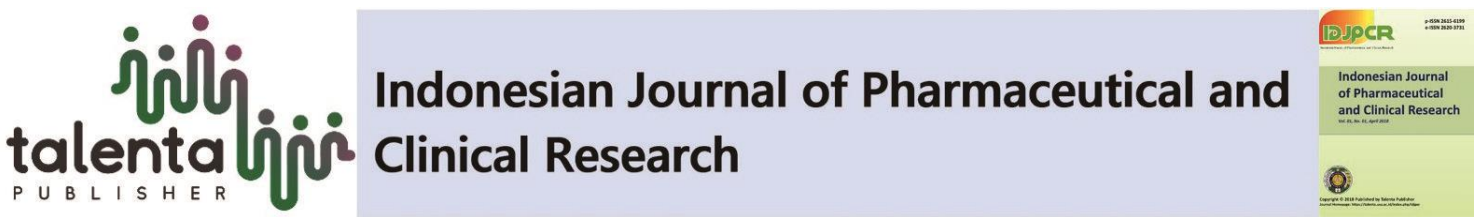

\section{The Effect of Boiling Time and the Type of Utensil Used on the Nitrite and Nitrate Contents in Carrots (Daucus carota L.)}

\author{
Jansen Silalahi, ${ }^{1,2 *}$, Shena Keshia Aritonang ${ }^{1}$, Muchlisyam ${ }^{1}$ \\ ${ }^{1}$ Faculty of Pharmacy, Universitas Sumatera Utara, Padang Bulan, \\ Medan 20155, Indonesia \\ ${ }^{2}$ Nanomedicine Center, Universitas Sumatera Utara, Padang Bulan, \\ Medan 20155, Indonesia
}

\begin{abstract}
The purpose of this study was to investigate the effect of boiling time using utensils made of different metal component on the nitrate and nitrite contents in carrots. The carrots were obtained from Jaranguda Village, Karo Regency, North Sumatra. The utensil types used for boiling were made of stainless steel, what so called periuk and aluminum and boiling time were 5 minutes, 10 minutes and 15 minutes. The determination of nitrite was done by visible spectrophotometer using sulfanilic acid and $\mathrm{N}$-(1-naphthyl) ethylenediamine dihydrochloride reagentsand absorbance was measured at a wavelength of $540 \mathrm{~nm}$. The determination of nitrate was carried out by reducing the nitrate into nitrite using Zinc powder and diluted $\mathrm{HCl}$ then measured as nitrite. The nitrite level was then converted into nitrate. The result showed that the utensil types and boiling time affected the levels of nitrate and nitrite in carrots. The nitrate and nitrite levels in fresh carrots was $32.14 \mathrm{mg} / \mathrm{kg}$ and $24.78 \mathrm{mg} / \mathrm{kg}$ respectively. After boiling for 5 minutes, the nitrate and nitrite levels decreased significantly. Further boiling of boiled carrots, the nitrite level increased in the aluminum utensil from $11.00 \mathrm{mg} / \mathrm{kg}$ to $20.15 \mathrm{mg} / \mathrm{kg}$ (83\%); in periuk from $9.18 \mathrm{mg} / \mathrm{kg}$ to $16.95 \mathrm{mg} / \mathrm{kg}$ (78\%) and in stainless steel from $8.21 \mathrm{mg} / \mathrm{kg}$ to $11.75 \mathrm{mg} / \mathrm{kg}$ (43\%). While the nitrate level decreased in aluminum utensil from $27.14 \mathrm{mg} / \mathrm{kg}$ to 21.08 $\mathrm{mg} / \mathrm{kg}$ (22\%); stainless steel from $16.40 \mathrm{mg} / \mathrm{kg}$ to $13.25 \mathrm{mg} / \mathrm{kg}(19 \%)$ and periuk from $20.30 \mathrm{mg} / \mathrm{kg}$ to $16.51 \mathrm{mg} / \mathrm{kg}(18 \%)$. The results of this study indicated that the nitrite level increased, while nitrate level decreased with boiling time. The effect of utensil type used on boiling increased nitrite but decreased nitrate level in carrots and these effects were found that the most influential treatment was using utensil made of aluminum.
\end{abstract}

Keyword: Carrot, Boiling Time, Nitrate, Nitrit, Utensil Type

Abstrak. Tujuan penelitian ini adalah untuk mengtahui pengaruh waktu perebusan dan jenis wadah yang digunakan yang terbuat dari logam yang berbeda terhadap kadar nitrat dan nitrit dalam wortel. Wortel diperoleh dari Kampung Jaranguda, Kabupaten Karo, Sumatera Utara. Wadah yang digunakan terbuat dari stainless steel, periuk biasa dan aluminum; waktu perebusan adalah 5, 10 dan 15 menit. Penentuan kadar nitrit dengan spectrofotometer visibel menggunakan reagen asam sulfanilat dan $N$-(1-naftil) etilendiamine dihidroklorida, dan absorbansi diukur pada panjang gelombang $540 \mathrm{~nm}$. Penentuan kadar nitrat dilakukan setelah mereduksi nitrat menjadi nitrit menggunakan serbuk seng dan $\mathrm{HCl}$ encer kemudian ditentukan sebagai nitrit, kemudian kadar nitrit diubah menjadi kadar nitrat. Kadar nitrat and nitrit di dalam wortel segar masing-masing adalah $32.14 \mathrm{mg} / \mathrm{kg}$ dan $24.78 \mathrm{mg} / \mathrm{kg}$. Pada perebusan selama 5 menit kadar nitrat dan nitrit menurun secara sigifikan. Pada perebusan selanjutnya, kadar nitrit meningkat dalam

${ }^{*}$ Corresponding author at: Universitas Sumatera Utara, Medan, Indonesia

E-mail address: jansen@usu.ac.id 
wadah aluminum dari $11.00 \mathrm{mg} / \mathrm{kg}$ menjadi $20.15 \mathrm{mg} / \mathrm{kg}$ (83\%); pada wadah periuk dari $9.18 \mathrm{mg} / \mathrm{kg}$ menjadi $16.95 \mathrm{mg} / \mathrm{kg}(78 \%)$, dalam wadah stainless steel dari $8.21 \mathrm{mg} / \mathrm{kg}$ menjadi $11.75 \mathrm{mg} / \mathrm{kg}$ (43\%). Sedangkan kadar nitrat menurun di dalam wadah aluminium dari $27.14 \mathrm{mg} / \mathrm{kg}$ menjadi $21.08 \mathrm{mg} / \mathrm{kg}$ (22\%); wadah stainless steel dari $16.40 \mathrm{mg} / \mathrm{kg}$ menjadi $13.25 \mathrm{mg} / \mathrm{kg}$ (19\%); di dalam wadah periuk dari $20.30 \mathrm{mg} / \mathrm{kg}$ menjadi 16.51 $\mathrm{mg} / \mathrm{kg}(18 \%)$. Hasil penelitian menunjukkan bahwa kadar nitrit meningkat sedangkan nitrat menurun selama perebusan. Pengaruh jenis wadah perebusan meningkatkan kadar nitrit tetapi sebaliknya menurunkan kadar nitrat di dalam wartel, dan jenis wadah perbusan yang paling berpengaruh adalah perebusan dengan wadah yang terbuat dari aluminum.

Kata kunci: Wortel, Lama Perebusan, Nitrat, Nitrit, Jenis Wadah.

Received 05 June 2017 | Revised 24 October | Accepted 12 March 2018

\section{Introduction}

Nitrate is a natural compound in vegetables. Plants need nitrate, because it is necessary for growth and photosynthesis. Nitrate is metabolized in plant by nitrate reductase enzyme into nitrite [1]. Vegetables are the main source of nitrates and nitrites in the human diet. Vegetables contain nitrate and nitrite at high amounts which contribute to around 80-92\% of average daily intake. Nitrate content in vegetables ranging from 1 to $10.000 \mathrm{mg} / \mathrm{kg}$ wet base. In addition, nitrate and nitrite are also added in processed meat products as preservative against microorganisms mainly Clostridium botulinum that may cause food poisoning. Therefore nitrates and nitrites are necessary monitored regularly because of their toxicities [2,3]. Total nitrite intake should be limited because it can react with primary and secondary amines to form carcinogenic nitrosamines in acidic condition such as in stomach. Therefore the permitted total intakes of nitrate and nitrite (Acceptable Daily Intake $=$ ADI) regulated by FAO/WHO for adult with the body weight of $60 \mathrm{~kg}$ are $220 \mathrm{mg}$ and $8 \mathrm{mg}$, respectively [3,4].

Vegetables are usually cooked or prepared by boiling, frying or steaming. This cooking process may change vegetable composition either in positive or negative way [5]. Vegetable is usually processed by boiling in utensil made of different metal component such as aluminum, zinc, iron, chromium andin combination with different reactivity in water affected by heat on cooking process [6]. Some utensils are made of stainless steel composed of chromium 14-18\% and nicel $7-9 \%$ [7]. A previous study reported that $0.1 \mathrm{mg} \mathrm{Al} / 100 \mathrm{~g}$ was found in food after cooking in aluminum utensil [8].

Nitrate in food is quite stable but it is reduced into nitrite when comes into contact with aluminum. Therefore, using type of utensil made of different metal component may differently affect on nitrate and nitrite content in vegetables. The carrots contain nitrate within the range of $0-2800 \mathrm{mg} / \mathrm{kg}$, is commonly consumed as valuable vegetable due to the high contents of $\alpha$ - and $\beta$-carotene and becomes the source of pro-vitamin $\mathrm{A}[1,9,10]$. 
The aim of this study was to investigate the effect of boiling time and the type of utensil used on the nitrite and nitrate contents in carrots. The determination of nitrite and nitrate levels were done with visible Spectrophotometric method. The determination of nitrite was done using sulfanilic acid and $\mathrm{N}$-(1-naphthyl) ethylenediamine dihydrochloride reagents at the wavelength of $540 \mathrm{~nm}$ [11]. The nitrate was reduced into nitrite then analyzed as nitrite, then converted into nitrate by molecular weight ratio $[12,13]$.

\section{Materials and Method}

\subsection{Materials}

The carrots were collected from Jaranguda Village, Karo Regency, North Sumatra. The utensil types used for boiling were made of stainless steel, periuk and aluminum. The chemicals used were pro analysis grade product of E. Merck (Germany) including; N-(1naphthyl) ethylenediamine dihydrochloride (NED), sodium nitrite, sulfanilic acid, glacial acetic acid, hydrochloric acid, ferrous sulfate, concentrated sulfuric acid, sodium hydroxide, potassium permanganate, zinc powder, and distilled water.

\subsection{Instruments}

The instruments used in this study were spectrophotometer UV-Vis (UV- 1800 Shimadzu), analytical balance (Boeco Germany), water bath, filter paper, thermometer, stirring rod and necessary glass wares.

\subsection{Boiling Process}

The fresh carrots $( \pm 10 \mathrm{~g}$ ) were placed in aluminum pan, periuk (utensil made of combination of different metals) and stainless steel pan containing $500 \mathrm{ml}$ of boiling water. The boiling process was carried out for 5, 10 and 15 minutes. This process was assumed to be similar to the normal households cooking.

\subsection{Preparation of Reagents}

Acetic acid solution of $15 \%$ was prepared by dissolving $75 \mathrm{ml}$ glacial acetic acid and diluted with distilled water to make $500 \mathrm{ml}$. NED solution was made by dissolving $0.350 \mathrm{~g} \mathrm{~N}$-(1naphthyl) ethylenediamine dihydrochloride in $250 \mathrm{ml}$ acetic acid solution $15 \%$, filtered and stored in brown bottle. Sulfanilic acid solution was prepared by dissolving $0.850 \mathrm{~g}$ sulfanilic acid in $250 \mathrm{ml}$ acetic solution of $15 \%$, filtered and stored in brown bottle [11,14].

\subsection{Preparation of Nitrite Standard Stock Solution}

The amount of $100 \mathrm{mg}$ sodium nitrite was transferred into $100 \mathrm{ml}$ volumetric flask and dissolved in distilled water, and then made to $100 \mathrm{ml}(1000 \mu \mathrm{g} / \mathrm{ml})$ (Solution I). From this 
solution $1 \mathrm{ml}$ was pipetted into $100 \mathrm{ml}$ volumetric flask and added distilled water to make 100 $\mathrm{ml}(10 \mu \mathrm{g} / \mathrm{ml})$ (Solution II).

\subsection{Identification of Nitrite and Nitrate}

Some amount of ground sample of each treatment was transferred into beaker glass, added distilled water, heated in water bath and shaken for a little while, then cooled and supernatant was collected and placed in a test tube for nitrite and nitrate identification. The presence of nitrite was identified with sulfanilic acid and NED solution and allowed for a little while. The presence of nitrate was tested by adding several drops ferrous sulfate solution and then few drops of concentrated sulfuric acid added slowly through the inner wall of the test tube, then the color produced was observed $[14,15]$.

\subsection{Determination of Absorbance Curve of Nitrite Standard Solution}

Four (4) $\mathrm{ml}$ of stock standard solution II $(10 \mu \mathrm{g} / \mathrm{ml})$ was transferred into $50 \mathrm{ml}$ volumetric flask, added $2.5 \mathrm{ml}$ of sulfanilic acid solution and shaken, after 5 minutes $2.5 \mathrm{ml}$ NED reagent was added and made to volume with distilled water and homogenized $(0.8 \mu \mathrm{g} / \mathrm{ml})$. Absorbance was measured at wave length of 400-800 $\mathrm{nm}$. Then absorbance and wave length was plotted automatically to construct absorbance curve. Wave length of maximum absorbance was determined from the absorbance curve. The maximum absorbance of standard solution was found at the wave length of $540 \mathrm{~nm}$ and used in the analysis.

\subsection{Absorbance Stability of Derivatized Nitrite to Determine Best Working Time}

Four (4) $\mathrm{ml}$ stock solution II transferred into volumetric flask of $50 \mathrm{ml}$, to which $2.5 \mathrm{ml}$ of sulfanilic acid solution was added and stirred. After 5 minutes, $2.5 \mathrm{ml}$ NED reagent solution was added then distilled water was added to make $50 \mathrm{ml}$. Absorbance was measured at wave-length of maximum absorbance $(540 \mathrm{~nm})$, and stability of absorbance was determined by observing absorbance at every minute for 1 hour. The absorbance was found to be relatively stable during period after five to eight minutes (5-8 minutes).

\subsection{Determination of Calibration Curve}

Standard stock solution II $(10 \mu \mathrm{g} / \mathrm{ml})$ of different volumes $(0.5 \mathrm{ml} ; 1 \mathrm{ml} ; 2 \mathrm{ml} ; 3 \mathrm{ml}, 4 \mathrm{ml}$, dan 5 $\mathrm{ml}$ ) were transferred into different volumetric flasks of $50 \mathrm{ml}$, then $2.5 \mathrm{ml}$ sulfanilic acid reagent added and stirred to homogenize. After 5 minutes, $2.5 \mathrm{ml}$ NED reagent was added, then distilled water was added to make volume of $50 \mathrm{ml}$ and homogenized. The concentrations of prepared solutions were of $0.1 \mu \mathrm{g} / \mathrm{ml} ; 0.2 \mu \mathrm{g} / \mathrm{ml} ; 0.4 \mu \mathrm{g} / \mathrm{ml} ; 0.6 \mu \mathrm{g} / \mathrm{ml} ; 0,8 \mu \mathrm{g} / \mathrm{ml} ; 1.0 \mu \mathrm{g} / \mathrm{ml}$. Absorbance of each solution was measured at wave-length of $540 \mathrm{~nm}$ after about 7 minutes. Calibration curve was constructed by plotting absorbance versus concentration of each solution. From the graph obtained, then linearity of regression equation and correlation coefficient were calculated. From the experiment was found that regression equation was $\mathrm{Y}=0.5818 \mathrm{X}+0.0012$, and 
correlation coefficient was $0.9998 . \mathrm{Y}=$ absorbance; $\mathrm{X}=$ Nitrite concentration in diluted sample solution $(\mu \mathrm{g} / \mathrm{ml})$.

\subsection{Determination of Nitrite and Nitrate in Carrots}

The determination of nitrite and nitrate levels in vegetables were carried out according to the procedure described in Association Official Methods Of Analytical Chemists (AOAC) XVII edition [11]. Ten (10) gram ground sample was transferred into $250 \mathrm{ml}$ beaker glass. Then, hot distilled water $\left( \pm 80^{\circ} \mathrm{C}\right)$ was added to make volume of $150 \mathrm{ml}$. Homogenized by stirring and heated on water-bath for 15 minutes while stirring. Allowed to cool and then transferred quantitatively into a volumetric flask of $250 \mathrm{ml}$. Distilled water was added to make volume of $250 \mathrm{ml}$, and then filtered. About $10 \mathrm{ml}$ first filtrate was discarded, the following filtrate was collected. The filtrate obtained was used firstly for nitrite and then for nitrate quantification. For the nitrite level determination ten $(10 \mathrm{ml})$ of filtrate transferred into a volumetric flask of $50 \mathrm{ml}$, then $2.5 \mathrm{ml}$ sulfanilic acid reagent was added and stirred. After 5 minutes, $2.5 \mathrm{ml}$ reagent NED was added, then distilled water was added to make $50 \mathrm{ml}$, and then homogenized. Absorbance was measured at wave-length of $540 \mathrm{~nm}$ after period of 5 to 8 minutes time.

The determination of nitrate was done after reducing nitrate into nitrite and determined as nitrite $[14,15]$. Ten (10) $\mathrm{ml}$ of filtrate prepared above was transferred into a volumetric flask of $50 \mathrm{ml}$ added Zinc powder $(1 \mathrm{~g})$ and $1 \mathrm{ml}$ hydrochloride acid $0.1 \mathrm{~N}$, shaken and allowed to stand for 10 minutes, then $2.5 \mathrm{ml}$ sulfanilic acid reagent was added and stirred to homogenous. After 5 minutes, $2.5 \mathrm{ml}$ reagent NED was added, then distilled water was added to make $50 \mathrm{ml}$, then homogenized. Absorbance was measured at wave-length of $540 \mathrm{~nm}$ after period of 5 to 8 minutes time. The absorbance measured in this step was resulted from total nitrite (initial nitrite plus nitrite from reducing nitrate into nitrite). Dilution factor was $5(10 \mathrm{ml}$ filtrate to $50 \mathrm{ml})$. Concentration of nitrite in diluted sample filtrate was calculated from the regression equation obtained from calibration curve: $\mathrm{Y}=0.5818 \mathrm{X}+0.0012$

Nitrite concentration in the sample could be calculated by the following formula:

$\mathrm{C}=\frac{\mathrm{XxV} \times \mathrm{Fp}}{\text { Sampel weight }(\mathrm{g})}$

Notes:

$\mathrm{Y}=$ Absorbance

$\mathrm{C}=$ concentration of nitrite in sample $(\mu \mathrm{g} / \mathrm{g})$

$\mathrm{X}=$ Nitrite concentration in diluted sample solution $(\mu \mathrm{g} / \mathrm{ml})$

$\mathrm{V}=$ volume of sample solution before dilution $(\mathrm{ml})$

$\mathrm{Fp}=$ dilution factor (5)

Concentration of nitrite from the reduction of nitrate into nitrite $=$ concentration of total nitrite after reduction - concentration of nitrite before reduction.

Nitrate concentration $=$ nitrite concentration from the reduction $\mathrm{xW} \frac{\text { MWitrate }}{\text { MWitrite }}$ 


\section{Results and Discussion}

\subsection{Identification of Nitrite and Nitrate in Carrot}

From the identification tests it was proved that the nitrite and nitrate levels were present in carrots. Based on the test conducted after boiling with various time, the levels of nitrite and nitrate were found to increase indicated by the increasing intensity of color produced by the test conducted after boiling. The appearance of violet color resulted from the reaction of the sample solution with sulfanilic acid and NED solution was to indicate the presence of nitrite. The presence of nitrate was indicated by the appearance of chocolate ring $[14,15]$.

\subsection{Absorption Curve of Nitrite and Determination of Working Time}

Absorption curve was determined by measuring absorbance of standard solution of $0.8 \mu \mathrm{g} / \mathrm{ml}$ after derivatization with NED reagent. Measurement was carried out using wave length ranging from $400-800 \mathrm{~nm}$. From the absorption curve found that maximum absorption of standard solution was found to be at $540 \mathrm{~nm}$ and this result is similar to that mentioned in AOAC [11]. This wave length was used to determine the appropriate working time by measuring absorbance of standard solution of $0.8 \mu \mathrm{g} / \mathrm{ml}$ for 60 minutes and absorbance was found to be relatively stable about seven minutes (after 5 to 8 minutes). So that working time was 7 minutes (after 5 to 8 minutes during measurement).

\subsection{The Effect of Boiling Time with Different Type of Utensil Used on The Nitrite and Nitrate Contents in Carrots}

The effect of boiling time using different type of utensil on the nitrite and nitrate contents in carrots was presented in Table 1 and Figure 1. From Table 1 and Figure 1 could be seen that the nitrate content $(32.14 \mathrm{mg} / \mathrm{kg})$ was higher than nitrite $(24.78 \mathrm{mg} / \mathrm{kg})$ in fresh carrots, since more than $90 \%$ of the nitrogen absorbed by plants in the form of nitrate, and in addition nitrate is necessary for plant growth and to produce protein $[1,14]$.

\subsection{The Nitrate and Nitrite Contents in Carrots}

Initial boling (for 5 minutes) of fresh carrot decreased both nitrite and nitrate levels [15]. However, further boiling, the results showed that the boiling time with different type of utensil used affecting of the nitrate and nitrite levels in carrots. As shown in Table 1 and Figure 1, the effect of time and utensil type used for boiling increased the nitrite but decreased nitrate levels in carrot and this effect was found to be the most significant in aluminum utensil. The longer the boiling time the lower nitrate and the higher nitrite contents in carrots. 
Table 1. The Effect of Boiling Time with Different Type of Utensil Used on the Nitrate and Nitrite Contents of Carrots

\begin{tabular}{cccc}
\hline $\begin{array}{c}\text { Type of } \\
\text { Utensil used } \\
\text { on Boiling }\end{array}$ & Boiling Time $(\mathbf{m i n})$ & $\begin{array}{c}\text { Nitrite Content } \\
(\mathbf{m g} / \mathbf{k g}) \pm \mathbf{S D}\end{array}$ & $\begin{array}{c}\text { Nitrate Content } \\
(\mathbf{m g} / \mathbf{k g}) \pm \mathbf{S D}\end{array}$ \\
\hline- & 0 (fresh) & $24.78 \pm 0.238$ & $32.14 \pm 0.588$ \\
Stainless steel & 5 & $8.21 \pm 0.082$ & $16.40 \pm 0.167$ \\
& 10 & $10.20 \pm 0.317$ & $14.01 \pm 0.578$ \\
& 15 & $11.75 \pm 0.103$ & $13.25 \pm 0.546$ \\
Periuk & 5 & $9.18 \pm 0.304$ & $20.30 \pm 0.568$ \\
& 10 & $14.10 \pm 0.030$ & $17.96 \pm 0.303$ \\
& 15 & $16.95 \pm 0,013$ & $16.51 \pm 0.118$ \\
& 5 & $11.00 \pm 0.252$ & $27.14 \pm 0.261$ \\
& 10 & $15.06 \pm 0.033$ & $23.53 \pm 1.010$ \\
& 15 & $20.15 \pm 0.116$ & $21.08 \pm 0.154$ \\
\hline & & & \\
\hline
\end{tabular}

Note: Data is the mean of 6 replicates \pm Standard deviation

The type of utensil used on further boiling (after 5 minutes) also affected differently; it increased the nitrite but decreased nitrate contents in carrots. The nitrate and nitrite levels in fresh carrots without boiling ( 0 minutes) were $32.14 \mathrm{mg} / \mathrm{kg}$ and $24.78 \mathrm{mg} / \mathrm{kg}$, then decreased after 5 minutes on boiling in water due to the conversion of nitrate and nitrite from carrot into the hot water $[15,16,17]$. Further boiling, the nitrite level increased in aluminum utensil was the most influential factor, increased from $11.00 \mathrm{mg} / \mathrm{kg}$ to $20.15 \mathrm{mg} / \mathrm{kg}$ (83\%); in periuk from 9.18 $\mathrm{mg} / \mathrm{kg}$ to $16.95 \mathrm{mg} / \mathrm{kg}(78 \%)$ and in stainless steel from $8.21 \mathrm{mg} / \mathrm{kg}$ to $11.75 \mathrm{mg} / \mathrm{kg}(43 \%)$. On the other hand, the nitrate levels decreased in aluminum utensil from $27.14 \mathrm{mg} / \mathrm{kg}$ to 21.08 $\mathrm{mg} / \mathrm{kg}(22 \%)$; stainless steel from $16.40 \mathrm{mg} / \mathrm{kg}$ to $13.25 \mathrm{mg} / \mathrm{kg}(19 \%)$ and periuk from 20.30 $\mathrm{mg} / \mathrm{kg}$ to $16.51 \mathrm{mg} / \mathrm{kg}(18 \%)$. The level of nitrate found in this study was within the range of 0 $2800 \mathrm{mg} / \mathrm{kg}$ in carrots [1]. 


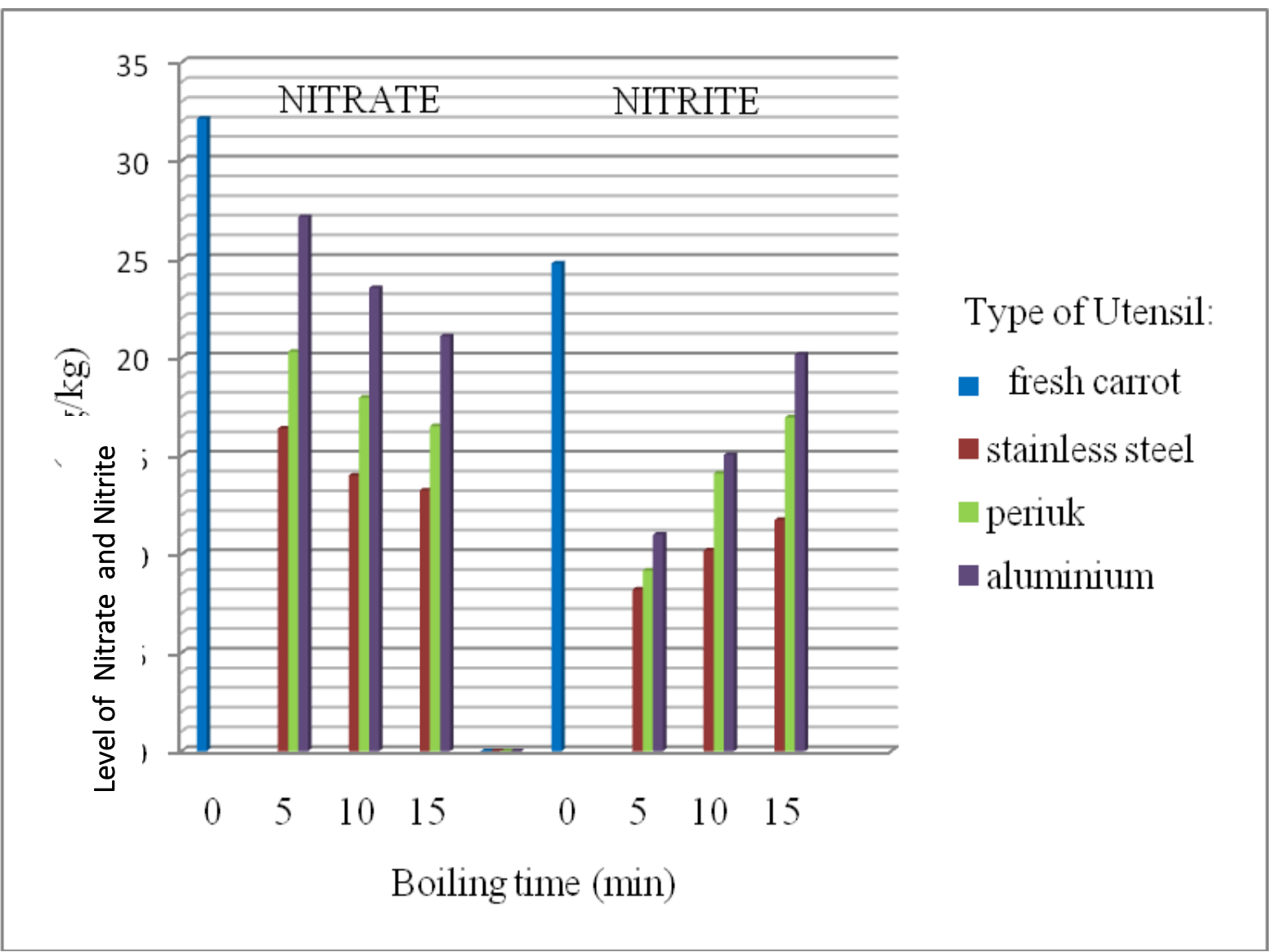

Figure 1. The Effect of Boiling Time with Different Type of Utensil Usedon the Nitrate and Nitrite Contents in Carrots

The utensil type used on cooking differently affected the levels of nitrate and nitrite. The nitrate was decreased while nitrite was increased because nitrate was reduced to nitrite due to the contact with metal derived from the utensil used during boiling [1]. In a research conducted to detect the levels of aluminum in food cooked in aluminum pans found that aluminum at the level of about $0.1 \mathrm{mg}$ per $100 \mathrm{~g}$ was detected for most meals [8].

Different effect by different type of the utensil used could be due to the different reactivity of different metal component in the utensil. Aluminum is more reactive than periuk and the stainless steel is the least, therefore, the effect of aluminum utensil was the most influential and stainless steel was the least [18].

A side from being a source of nitrate, vegetable is a major source of ascorbic acid. Ascorbic acid can inhibit the synthesis of nitrosamines and lower the risk methaemoglobinemia, but boiling vegetables will degrade vitamin $\mathrm{C}$ so that the synthesis of nitrosamine is not inhibited $[3,19,20]$. 


\section{Conclusion}

The results showed that the utensil types used and the time of boiling affected the levels of nitrate and nitrite in carrots. The nitrate and nitrite levels in fresh carrots decreased significantly on boiling after 5 minutes. Further boiling (longer then 5 minutes); the nitrite level constantly increased while the nitrate level decreased. These effects were found to be the most influential using aluminum utensil and the least effect was with stainless steel.

\section{REFERENCES}

[1] M. J. Hill, "Nitrates and Nitrites From Food and Water in Relation to Human Disease," Nitrates And Nitrites In Food And Water”, pp. 163-193 1996.

[2] S.S. Chou, J.C. Chung, and D.F. Hwang, "A High Performance Liquid Chromatography Method for Determining Nitrate and Nitrite Levels in Vegetables". Journal of Food and Drug Analysis, vol. 11, no. 3, pp. 223, 227. 2003

[3] J. Silalahi, "Negative impact of Nitrate and Nitritein Foods". Medika: Jurnal Kedokteran Indonesia. Vol. 31, no. 5, pp. 460-462. 2005

[4] S. S. Mirvish, "Chapter 18 Methods for the Determination of N-Nitroso Compounds in Food and Biological Fluids," Comprehensive Analytical Chemistry, pp. 653 - 684. 2008.

[5] T. Ramdhan, and S. Aminah, "The effect of boiling on antioxidant contents in vegetables". Jakarta, p 7-8. 2014

[6] M.C. Williams, Food Fundamentals. John Wiley and Sons Toronto, New York:, p 28-29. 1979

[7] A Sidharta, and Indrawati, Materials: Properties and their use. Pusat Pengembangan dan Pemberdayaan Pendidik dan Tenaga Kependidikan Ilmu Pengetahuan Alam PPPPTK IPA, Bandung, p 31,33. 2009.

[8] R. Massey, and D. Taylor, Aluminum in Food and the Environment. The Royal Society of Chemistry, London, p 92-96. 1988.

[9] N.B.V. Ali, and E. Rahayu, Carrot and Radish, Penebar Swadaya, Jakarta, p 5.1995.

[10] V. E. Rubatzky and M. Yamaguchi, Vegetables World 2. Principles, Production and Nutrition. Institut Teknologi Bandung, Bandung, p. 163. 1997.

[11] J. Hess, Association Official Methods of Analytical Chemists, $17^{\text {th }}$ Edn, AOAC Inc, Virginia, p 8. 2000.

[12] H. E. Rogers, "A textbook of macro and semimicro qualitative inorganic analysis," Journal of Chemical Education, vol. 33, no. 2, p. 98, Feb. 1956.

[13] J. Silalahi, C.A. Dalimunthe, S.S.Dewi,"Analysis of Nitrite and Nitrate in Drinking Water". Medika: Jurnal Kedokteran Indonesia.. p 306-309. 2007

[14] H. Cintya, J. Silalahi, E. De Lux Putra, and R. Siburian, "The influence of storage condition on nitrite, nitrate and vitamin C levels in vegetables," F1000Research, vol. 7, p. 1899, Dec. 2018.

[15] J. Silalahi, F. Sitanggang, and Muchlisyam, "The Effect of Boiling on Nitrite and Nitrate contents in Celery (Apium graveolens L)", International Journal of PharmTech Research, vol 9, no. 11, pp 218-223. 2016

[16] J. C. Huarte-Mendicoa, I. Astiasarán, and J. Bello, "Nitrate and nitrite levels in fresh and frozen broccoli. Effect of freezing and cooking," Food Chemistry, vol. 58, no. 1-2, pp. 39-42, Jan. 1997.

[17] D. Lund, "Effects of Heat Processing on Nutrients," Nutritional Evaluation of Food Processing, pp. 319-354. 1988.

[18] Je. Brady, and .R. Holum, Chemistry: The Study of Matter and It's Changes, John Wiley \& Sons, Singapore, pp. 532-535. 1993

[19] J. Raczuk,W. Wadas, dan L. Glozak, "Nitrates and Nitrites In Selected Vegetables Purchased At Supermarkets in Siedlce", Poland. Rocz Panstw ZaklHig, vol.65, no,1:16, pp.18-19. 2014. 
[20] S. Vahed, L. Mosafa, M. Mirmohammadi, and L. Lakzadeh, "Effect of some processing methods on nitrate changes in different vegetables," Journal of Food Measurement and Characterization, vol. 9, no. 3, pp. 241-247, Feb. 2015 